Submitted $21^{\text {th }}$ June 2021

Accepted $28^{\text {th }}$ June 2021

\title{
THE UNIQUENESS OF MEGERET PANDAN TRADITION AS TOURIST ATTRACTION IN TENGANAN VILLAGE, KARANGASEM, BALI
}

\author{
Anak Agung Istri Putera Widiastiti ${ }^{1}$, Anak Agung Istri Ngurah Dyah Prami ${ }^{2}$ \\ ${ }^{1}$ The International Institute of Tourism and Business, Indonesia \\ ${ }^{2}$ STIE Bali International Institute of Tourism Management, Indonesia \\ raradeta.widiastiti@gmail.com,dyahprami@yahoo.co.id
}

\begin{abstract}
Megeret Pandan or mekare-kare is a tradition in Tenganan Village, Karangasem. This tradition is related to local ritual activities and beliefs in which all men from children to adults take turn performing in an arena to play dexterity match as fighters by using pandan leaves, a shield from rattan wicker and traditional costume. This tradition is potential to be tourist attraction since the tourists are welcome to participate. The purpose of this study is to determine the existence the tradition of Megeret Pandan as a tourist attraction in Tenganan Village and its relation to the defense of ancestral heritage. This study used qualitative method and it was conducted through inductive process. The theory was Structural Functional Theory of Talcott Parson concerning action system, in which the objective conditions were united with collective commitment upon certain value for the development of a social action form. Based on the research finding, it was concluded that the tradition of Megeret Pandan which was packaged in such a way as tourist attraction could be tourist attraction without leaving the sacred values within.
\end{abstract}

Keywords: Megeret Pandan; Tourism attraction; Sacred tradition

\section{INTRODUCTION}

Tenganan Village is one of the tourist villages in Bali. With the characteristics of Bali Aga Village, tenganan villagers are able to maintain their traditions. Tradition is a habit passed down from one generation to the next for generations. Inherited habits include various cultural values that include customs, community systems, knowledge systems, languages, arts, belief systems and so on. Cultural values become a guideline for behaving to the next generation. This process causes certain cultural values to become traditions that are usually maintained by the community.

Tradition is also a picture of human attitudes and behaviors that have been processed for a long time and carried out through generations from ancestors. Tradition as part of culture becomes a wealth of its own for the local village. The values contained in the tradition become a reference to various behaviors of the community. Society and culture are two singles that are difficult to distinguish, in which implied a unified knowledge with beliefs and values, which determine the situation and conditions of behavior of members of the community (Ghazali, 2011: 34-35). Tradition in TengananVillage has its own uniqueness so that it can be a 
tourist attraction that is in demand by tourists.

One of the traditions that developed in tenganan village community is Mekare-kare tradition or better known by the community as Megeret Pandan tradition (perang pandan). Megeret Pandan tradition is a series of special ritual ceremonies in Tenganan Village held once a year, performed in the framework of Aci Usabha Sambah which falls on the fifth sasih according to the typical dating system of Tenganan Village. This ceremony lasts for several weeks with a series of interesting traditional ceremonies and the culmination is held Megeret Pandan ritual.

Research that has been done previously on the Megeret Pandan tradition, by Artadia and Saptono about "Analisis Ritual Perang Pandan Berbasis Perspektif Diakronis di Desa Wisata Tenganan Pegringsingan" in 2019. The similarity with the research conducted is related to the location and research subject. The difference is that Artadia and Saptono's research more focus on the diachronic aspect, while in this paper it focuses more on the existence of the Megeret Pandan tradition as a tourist attraction (Artadi \& Nugroho, 2019) .

The uniqueness of Megeret Pandan tradition becomes its own attraction for tourists, both domestic and foreign tourists. This is because tourists can not only watch the Megeret Pandan ritual procession, but also can participate actively in carrying out the ritual as participants. The situation is an attraction for tourists as well as an interesting experience amidst the characteristics of Tenganan Village as a Bali Aga Village that is still very strong in carrying out the tradition of ancestors. The openness of public attitudes to allow outsiders in this case tourists to be active participation in the implementation of their rituals becomes unique in the midst of the condition of the community that does not want to get any influence of change from outside, especially to the traditions owned. Based on the background, the problem that will be described in this writing is (1) How unique is the tradition of Megeret Pandan as a tourist attraction in Tenganan Village and its relation to the defense of ancestral heritage?

\section{METHODOLOGY}

This research used the qualitative method, which started with observing and collecting data. Afterward, the obtained data were analyzed inductively and interpreted (Creswell, 2016: 5). Research location in Desa Tenganan, Kabupaten Karangasem, Bali. Things that underlie the choice of this location are because the Megeret Pandan tradition exists, develops, and is preserved in Tenganan Village. As a form of research with qualitative methods, the main instrument in this research is the researcher, supported with an interview guide, camera, tape recorder, and anecdotal record. The type of data in this research is qualitative data and presented in the form of words. In addition, primary data obtained through direct data collecting as well as secondary data sourced from previous research and from literature are also used. Data sources include primary data sources and secondary data sources. Determination of informants is achieved by using the purposive sampling technique, with key informants which are traditional leaders of the local community who understand the essence of the Megeret Pandan tradition. Data collecting techniques were carried out through observation, interviews, and 
literature study. The data obtained in the field were then analyzed descriptively, qualitatively, and interpretively.

\section{RESULTS AND DISCUSSIONS}

Megeret Pandan tradition as a ritual that aims to express gratitude to Ida Sang Hyang Widhi Wasa in her manifestation as Dewa Indra is closely related to the story of Mayadanawa. According to his story, Bali was once ruled by a desorant and authoritarian king. The cruel king named Mayadanawa even considered himself a god and forbade his people from performing religious rituals. Witnessing Mayadanawa's cruel and violent behavior, the Gods in Heaven were enraged who then sent Dewa Indra to control the situation. Long story short after successfully paralyzing Mayadanawa's forces through fierce fighting, Dewa Indra intends to celebrate through a ceremony called Aswamedha Yadjna, a ritual at the expense of Dewa Indra's beloved horse named Oncesrawa. But when the time came, the horse suddenly disappeared.

The Gods mobilized the entire population to search for the horse, but to no avail. After a long wait, the group led by Wong Peneges finally managed to find the horse in a state of already a carcass. Nevertheless, Dewa Indra still appreciated this finding and conferred a territory as wide as the smell of horse carcasses to Wong Peneges. With the tactic of ordering a wider area, Wong Peneges with the troupe cut the carcass of the horse, then disseminated. The area of distribution of the scent of horse carcasses is now referred to as Tenganan Village. To honor the greatness of Dewa Indra as the god of war, the community held a special ritual in the form of a dance that symbolizes the practice of war and until now known as the tradition of Megeret Pandan (Mekare-kare) or Pandan War in tenganan village (Artadi \& Nugroho, 2019).

The implementation of Megeret Pandan ritual in Bale Agung (In The Great Hall of Meeting); Petemu Kelod (meeting hall in the south); Petemu Kaja (meeting hall in the north); Petemu is in the middle (meeting hall in the middle/top of the ceremony). Then in the afternoon there was a ngundang. Those who are invited to support the tradition are: Juru Gambang, playing gamelan selonding and xylophone in Bale Agung as a complement to the ceremony, luanan, mangku, pasek, pande, and dukuh. Geguron sign of Megeret Pandan ritual will begin, preceded by mebuang and metabuh tuak ceremony.

Megeret Pandan ritual lasts for approximately 2 hours. After the ritual ended, the villagers served tenganan village's special cakes, bananas and tape. The participants involved in the implementation of the ritual Megeret Pandan, wounds due to exposure to pandan spines given boreh kare which is a special herb made of turmeric, galangal, and vinegar to treat wounds due to pandan spines, so that the wound quickly heals and does not cause infection. Furthermore, residents perform the ritual of mabuang nguduh tanah or surround the place of tuak tabuh each 3 times. After that the villagers get to Bale Agung or to bale agung petemu, then Megeret Pandan ritual is finished.

The uniqueness of Megeret Pandan tradition is an attraction for tourists. According to Suwena and Widyatmaja in Hani (2017), tourist attraction that is also called tourist attraction is a potential that becomes a driver of tourist presence to a tourist destination. There is no denying that the tourism industry has a considerable 
contribution to the change of Balinese performing arts. It tends to encourage people and artists in Bali to pack a tradition as a tourist show. Bali's tourism industry has brought two different influences on art life in Bali. On the one hand, the tourism industry has opened new jobs, especially for performance artists by holding regular performances in their hometowns. On the other hand, the tourism industry contributes to the commercialization of art in Bali with more and more forms of packaged art performances oriented towards tourism interests. This is realized because man not only adjusts to his environment and desires, but also with the help of others (Mar'at \& Kartono, 2010: 82).

Since the tourism industry has become one of the important components in Bali's economy, the dynamics and rhythms of local people's daily lives are also slowly changing. More and more people are entering the world of tourism industry: handicraft arts, hotels, restaurants, transportation and local arts. In order for them to succeed in tourism, everyone must make changes in cultural behavior by changing their daily living habits, from self-regulating to being governed by working hours. In Parson's view, the pattern of behavior that society shows can be seen as a component of cultural systems and social systems. Cultural systems are an abstract component of culture that is often called customs, while social systems include various human actions and activities in interacting between individuals in society (Koentjaraningrat, 2009: 180-181). Changes in people's behavior in this regard can be said to be oriented towards adjustment to the tourism industry. Similarly, the various commercialization of the performing arts for tourist shows purposes.

However, without stripping away the values of authenticity or Balinese identity inherent in it, Megeret Pandan tradition can still exist and invite tourist visits to Tenganan Village. With the ritual procession only once a year, the Megeret Pandan tradition is the moment that tourists have been waiting for. This fact shows that on the one hand tourism comes with its global culture, while on the other hand tourism can also force Balinese people not to move much from their cultural characteristics. Culture distinguishes society from another and binds to one unified view that creates uniformity of behaving and acting. In everyday life, society cannot be separated from cultural ties (Busro, 2018: 2). Tenganan Village community as one of Bali Aga Village in Bali, through Megeret Pandan ritual which is open to tourists, able to prove that the uniqueness of a tradition is precisely an attraction for tourists. Making a tradition a tourist attraction, does not mean that it changes what has been believed to be a belief towards the commercialization of art. The fact that the community as a unit has an important role in the formation of the behavior of its people (Skinner, 2013: 635).

Furthermore, tourists can not only witness the implementation of Megeret Pandan ritual, but also can be directly involved as participants. Tenganan Village community allows tourists to participate in the implementation of Megeret Pandan ritual as long as it meets the specified requirements. This tradition is carried out not only by young people but also children and parents. By grasping a bundle of pandan leaves in the right hand and a round shield of rattan webbing as a shield in the left hand, the two pairs of men fought each other like fighting and attempted to hit their opponent with a spiked pandan leaf weapon in his hand. When the pandan thorns 
tear the flesh of his back, fresh blood flows, so the atmosphere becomes very exciting, but thrilling and scary.

In this tradition it is not focus who wins and who loses. The value that is upheld is togetherness and joy has got the opportunity to participate in it sincerely with the joy of the ritual, or in Balinese terms called ngayah. A valuable experience will be felt by everyone including tourists involved, ranging from choosing pandan leaves that are many and strong, so that their opponents feel afraid to face them. Then when a pair of pandan warriors cheered with a burning spirit holding a bundle of pandan and rattan shields as a sign ready to fight in the arena. Then fight each other with spiked pandan leaves and pour fresh blood from the wounds from being hit by pandan spines. Some screamed in pain, cringed, or even laughed when their bodies were injured by pandan spines. The pandan war couple continued to alternately perform this procession. In the next moment, they take turns pulling out the pandan spines attached to each other's bodies. Then the bloody wound is given a traditional herb that has been provided to treat the wound to heal immediately. Then at the end of the procession, they hold a flowering event or eat together.

Open to the development of tourism, does not necessarily make the people of Tenganan Village change from habits and customs that are believed to be their native culture. Tenganan Villagers are still able to synergize with the development of tourism and maintain the authenticity of its culture. It becomes a selling point and increases the interest of tourists to witness the implementation of Megeret Pandan tradition.

\section{CONCLUSION}

Based on the description above, it can be concluded that the uniqueness of the Megeret Pandan tradition is able to function as a tourist attraction in Tenganan Village, Karangasem, Bali. The opportunity for tourists to be able to actively participate is also an important experience for tourists. Although the Megeret Pandan Tradition is used as a tourist attraction, Tenganan Villagers are still able to synergize with the developments of tourism and maintain the cultural authenticity of its culture. Without stripping away the values of authenticity or Balinese identity inherent in it, Megeret Pandan tradition can still exist and invite tourist visits to Tenganan Village.

\section{REFERENCE}

Artadi, I. K. A. M., \& Nugroho, S. (2019). Analisis Ritual Perang Pandan Berbasis Perspektif Diakronis di Desa Wisata Tenganan Pegringsingan. Jurnal Destinasi Pariwisata, 7(1).

Busro, M. (2018). Teori-Teori Manajemen Sumber Daya Manusia. Jakarta: Prenada Media.

Creswell, J. W. (2016). Research Design Pendekatan Kualitatif, Kuantitatif, dan Mixed (3rd ed.). Yogyakarta: Pustaka Belajar.

Ghazali, A. M. (2011). Antropologi Agama Upaya Memahami Keragaman, Kepercayaan, Keyakinan, dan Agama. Bandung: Alfabeta.

Hani, T. (2017). Persepsi Wisatawan Terhadap Mepantigan Sebagai Pariwisata Alternatif Di Pondok Mepantigan, Gianyar Bali. Skripsi. Sekolah Tinggi 
Pariwisata Bali Internasional Denpasar.

Koentjaraningrat. (2009). Pengangtar Ilmu Antropologi. Jakarta: Rineka Cipta. Mar'at, S., \& Kartono, L. I. (2010). Perilaku Manusia: Pengantar Singkat tentang Psikologi. Bandung: Refika Aditama.

Skinner, B. F. (2013). Ilmu Pengetahuan dan Perilaku Manusia. Yogyakarta: Pustaka Pelajar. 